\title{
Retraction Notice: G. Rajović, J. Bulatović, Plant and Animal Production in Montenegro with Overview of the Food Industry, International Letters of Chemistry, Physics and Astronomy, Vol. 63, pp. 57-66, 2016 \\ Editorial office of International Letters of Chemistry, Physics and Astronomy
}

\author{
Seestrasse 24c, CH-8806 Bach, Switzerland \\ ilcpa@scipress.com
}

This article has been retracted at the request of a Publisher's representative.

The article [1] has appeared to be a duplicate of the publication [2]. It was published online in the International Letters of Social and Humanistic Sciences in November 2015 and in the meantime in the International Letters of Chemistry, Physics and Astronomy (ILCPA) in January 2016. Following the Retraction Guidelines of the Committee on Publication Ethics [3], Editors have made a decision to retract the article published in the ILCPA journal on the basis of duplicate publication.

The authors have been informed about this decision in due course and they agreed to retract the article [1]. Therefore, the paper has been declared retracted and marked duly.

Editorial office would like to apologize to the readers of the Journal for this case remained undetected until now. Our aim is to ensure the publication of original quality scientific manuscripts only.

\section{References}

[1] G. Rajović, J. Bulatović, Plant and Animal Production in Montenegro with Overview of the Food Industry, International Letters of Chemistry, Physics and Astronomy. 63 (2016) 57-66. DOI: 10.18052/www.scipress.com/ILCPA.63.57.

[2] G. Rajović, J. Bulatović, Plant and Animal Production in Montenegro with Overview of the Food Industry, International Letters of Social and Humanistic Sciences. 63 (2015) 7-16. DOI: 10.18052/www.scipress.com/ILSHS.63.7.

[3] Committee on Publication Ethics, Retraction Guidelines. Available: https://publicationethics.org/files/retraction\%20guidelines.pdf. 